Contract No. and Disclaimer:

This manuscript has been authored by Savannah River Nuclear Solutions, LLC under Contract No. DE-AC09-08SR22470 with the U.S. Department of Energy. The United States Government retains and the publisher, by accepting this article for publication, acknowledges that the United States Government retains a non-exclusive, paid-up, irrevocable, worldwide license to publish or reproduce the published form of this work, or allow others to do so, for United States Government purposes. 


\title{
RADIOACTIVE WASTE MANAGEMENT IN THE CHERNOBYL EXCLUSION ZONE - 25 YEARS SINCE THE CHERNOBYL NUCLEAR POWER PLANT ACCIDENT
}

\author{
Boris Ya. Oskolkov, ${ }^{*}$ Mikhail D. Bondarkov, ${ }^{*}$ Lubov I. Zinkevich, ${ }^{\dagger}$ Nikolai I. \\ Proskura, ${ }^{\dagger}$ Eduardo B. Farfán ${ }^{*}$ and G. Timothy Jannik ${ }^{*}$ \\ *Chernobyl Center for Nuclear Safety, Radioactive Waste and Radioecology, International \\ Radioecology Laboratory, 07100, Slavutich, Ukraine. \\ ${ }^{\dagger}$ National Agency of Ukraine for the Chernobyl Exclusion Zone Management, \\ Chernobyl, Ukraine \\ ${ }^{\ddagger}$ Savannah River National Laboratory, Aiken, SC 29808, USA
}

\section{For reprints and correspondence contact:}

Eduardo B. Farfán, Ph.D.

Environmental Science and Biotechnology

Environmental Analysis Section

Savannah River National Laboratory

Savannah River Nuclear Solutions, LLC

773-42A, Room 236

Aiken, SC 29808

E-mail: Eduardo.Farfan@srnl.doe.gov

Phone: (803) 725-2257, Fax: (803) 725-7673

\section{Part of the Savannah River National Laboratory HPJ Special Issue}

October 2011 


\begin{abstract}
Radioactive waste management is an important component of the Chernobyl Nuclear Power Plant accident mitigation and remediation activities of the so-called Chernobyl Exclusion Zone. This article describes the localization and characteristics of the radioactive waste present in the Chernobyl Exclusion Zone and summarizes the pathways and strategy for handling the radioactive waste related problems in Ukraine and the Chernobyl Exclusion Zone, and in particular, the pathways and strategies stipulated by the National Radioactive Waste Management Program.
\end{abstract}

Key words: Radioactive waste, Chernobyl, ChNPP accident, Chernobyl Exclusion Zone 


\section{INTRODUCTION}

Developing a proper radioactive waste management program is significant for the nuclear power industry. Radioactive waste management, as well as nuclear safety and security problems, appears to be the major argument of those who oppose the use of nuclear energy. Currently, the operation of nuclear power plants throughout the world has accumulated approximately $2.2-2.4 \times 10^{6} \mathrm{~m}^{3}$ of radioactive waste with an activity of approximately $1.5 \mathrm{x}$ $10^{6} \mathrm{TBq}$ and about 233,000 tons $^{\S}$ of spent nuclear fuel (SNF) with an activity of $2.4-3.7 \mathrm{x}$ $10^{10} \mathrm{TBq}$ (IAEA 2008). The Chernobyl Exclusion Zone ${ }^{* *}(\mathrm{ChEZ})$ accumulated $14.0 \times 10^{6} \mathrm{~m}^{3}$ of radioactive waste with an activity of $0.76 \times 10^{6} \mathrm{TBq}$; resulting from the Chernobyl Nuclear Power Plant (ChNPP) accident in 1986, which is by a factor of 5.8 more than the existing operational waste of the nuclear power plants of the entire world with approximately half of its activity. Therefore, the radioactive waste of the ChEZ constitutes a significant fraction of the worldwide inventory (IAEA 2008). The authors quoted these numbers to emphasize that the worldwide problem of the radioactive waste management will not be resolved without a safe and secure disposition of the ChNPP accident related waste.

\section{CHARACTERISTICS, VOLUMES AND SOURCES AND RADIOACTIVE WASTE IN UKRAINE}

The use of nuclear technologies in Ukraine started long before the disintegration of the Soviet Union. The Physics and Engineering Institute in the city of Kharkov is one of the oldest institutions in the Soviet Union where nuclear physics research has been conducted

\footnotetext{
$\S$ Metric tons of heavy metal (MTHM)

${ }^{* *}$ Hereinafter, the Chernobyl Exclusion Zone is defined as the Ukrainian part of the territory from which the population was evacuated after the 1986 accident and which is under the jurisdiction of the National Agency of Ukraine for the Chernobyl Exclusion Zone Management.
} 
since 1930's. Currently, Ukraine has over 5,000 enterprises, organizations, and institutions that manufacture, store or transport radioactive materials or other sources of ionizing radiation. Ukraine inherited the entire radioactive waste infrastructure from the former Soviet Union, previously managed with the goals of minimizing the costs associated with waste processing and disposal, and delaying the final decisions on the final disposal of radioactive waste to the future generations.

It is a well-known fact that the bulk of the radioactive waste in Ukraine is generated by nuclear power plants (NPP). Currently, Ukraine operates 15 nuclear power reactors: 6 reactors at Zaporozhskaya NPP, 4 reactors at Rovenskaya NPP, 3 reactors at South Ukrainskaya NPP, and 2 reactors at Khmelnitskaya NPP. This operational waste is stored in specially designed storage facilities directly at the NPPs. The types and volumes of radioactive waste at the Ukrainian NPPs is presented in Table 1 and radioactive waste stored at the Ukrainian State Corporation Radon Storage Facilities is shown in Table 2 (MESU 2010).

It should be noted that the designs for these storage facilities were developed in late 1960s and they do not meet current international and national requirements and regulations. The radioactive waste generated in research, medical and industrial organizations is shipped into the regional storage facilities of the specialized enterprise UkrRadon ${ }^{\dagger \dagger}$ that were also built over 50 years ago and currently do not provide full compliance with the applicable safety regulations.

However, the great bulk of the radioactive waste in Ukraine resulted from the ChNPP accident of 1986 and accumulated in the ChEZ. The ChEZ Radioactive Waste Disposal

\footnotetext{
$\Uparrow$ The Ukrainian specialized state association Radon (UkrRadon) was founded in 1990 as an affiliation of the Ukrainian facility of the All-Union Enterprise Radon to implement activities associated with non-nuclear cycle radioactive waste management and mitigation of radiation accidents. UKrRadon includes the following eight specialized regional enterprises: State Specialized Enterprise Center for Processing and Disposal of Technogenic Waste (Tekhnocenter, Chernobyl, CEZ), five state inter-regional specialized combines (GMSK) and one state specialized combine (GSK): Dnepropetrovsky GMSK, Kievsky GMSK, Lvovsky GMSK, Odessky GMSK, Kharkovsky GMSK, and Donetsky GSK.
} 
Storage (RWDS) ${ }^{\ddagger}$ and Radioactive Waste Interim Localization Sites (RWILS) ${ }^{\S \S}$ contain $1,928,107 \mathrm{~m}^{3}$ of radioactive waste with a total activity of 7,260 $\mathrm{TBq}$ (Table 3 ). In addition, the storage facilities of the ChNPP contain $519 \mathrm{TBq}\left(22,117 \mathrm{~m}^{3}\right)$ of solid and liquid radioactive waste resulting from the operation of the ChNPP reactors (Table 4).

In addition, large quantities of radioactive waste are held in the Shelter Facility that, according to its official status, can be functionally defined as a location for surface disposal of "unorganized" radioactive waste (unorganized radioactive waste storage facility undergoing the phase of stabilization and refurbishment) (MHU 1997). The volume of radioactive waste in the Shelter Facility is estimated to be $385,200 \mathrm{~m}^{3}$, including 1,250 tons of lava-like fuel masses, 50 tons of dust containing over $1 \%$ of the nuclear fuel, 22,240 tons of metal structures with the surface contamination equaling to the equivalent dose rate of over $10 \mathrm{mSv} \mathrm{hr}^{-1}$ and $3,000-5,500 \mathrm{~m}^{3}$ of contaminated aqueous masses identified as liquid radioactive waste. The volume of radioactive waste in the soils of the Shelter Facility is estimated to be $277,300 \mathrm{~m}^{3}$ (ChNPP 2006)

The total volume of radioactive waste in the Chernobyl Exclusion Zone including contaminated soils (i.e., soils with the contamination levels exceeding the maximum allowable contamination levels) is estimated to be $13,960,000 \mathrm{~m}^{3}$ with the activity of approximately 755.7 PBq (Table 5). The major quantities of the ChEZ waste are associated with the soils and the highest activity is consolidated in the Shelter Facility. The conversion of the Shelter Facility into an environmentally safe system is stipulated in the National Program for Decommissioning of the Chernobyl NPP and Conversion of the Shelter Facility into an Environmentally Safe System (VRU 2009). The Program calls for construction of a new Safe Containment followed by retrieval of the fuel containing materials and disposal of all high-level waste of the facility in compliance with the regulatory requirements. The status

\footnotetext{
\$ The Ukrainian abbreviation of Radioactive Waste Disposal Storage (RWDS) is PZRO.

$\S \S$ The Ukrainian abbreviation of Radioactive Waste Interim Localization Sites (RWILS) is PVLRO.
} 
of the Shelter Facility and its safety assessment were described in the literature in a great detail (ChNPP 2006, 2008) and therefore this article does not address these issues.

The radioactive waste associated with the ChEZ soils presents a serious problem due to its large volume and practical uncontrollability. It acts as a source of contamination for the Pripyat and the Dnieper Rivers that have an essential economic significance for the country (Fig. 1). The radionuclide intake from the territory of the ChEZ results in up to $64 \%$ of the total ${ }^{90} \mathrm{Sr}$ activity carried by the Pripyat River to the Dnieper River. Only in 2009, 0.97 and $0.39 \mathrm{TBq}$ of ${ }^{90} \mathrm{Sr}$ entered the Pripyat and Dnieper Rivers due to washout and seepage, respectively. In 2009 , the ${ }^{90} \mathrm{Sr}$ carried into the Dnieper River by the rivers of the Chernobyl Exclusion Zone was $1.75 \mathrm{TBq}$.

Although, for the last few years, no increase over the maximum allowable radionuclides content has been recorded in the Pripyat and the Dnieper rivers, the radionuclide intake into the major water arteries of the country proves to be an unfavorable factor, increasing the total exposure dose for the public. Unfortunately, no detailed assessments of the radiation risks associated with the ChEZ contaminated soils have been available so far. No acceptable solutions on the management strategy for the contaminated soils have been available either.

The second source of radioactive waste in the ChEZ is associated with the RWILS originating from the decontamination activities in the first phase of the ChNPP 1986 accident mitigation period (Fig. 2). The decontamination of the highly contaminated area of the ChNPP site, the adjacent construction warehouse (Stroybaza), so called Red Forest ${ }^{* * *}$, the City of Pripyat, and a few settlements of the ChNPP proximity zone resulted in a large quantity of radioactive waste, such as contaminated structures, removed earth, trees, metal, etc. In 1986 - 1987, such waste was buried in trenches that were dug in-situ, without

\footnotetext{
*** The "Red Forest" is an approximately $5 \mathrm{~km}^{2}$ (500 ha) wooded area west of the ChNPP containing pine trees that died due to radiation exposure. The Red Forest received its name because of a yellow reddish color of the pine needles of the dead trees. In 1988, the Red Forest was buried in in-situ trenches.
} 
providing insulation or other measures that would have prevented radionuclide transport into the environment. By May of 1989, approximately $4 \mathrm{~km}^{2}$ (400 ha) of the soils reportedly were contaminated in such a manner that resulted in the creation of the RWILS sites containing about $1.1 \times 10^{6} \mathrm{~m}^{3}$ of solid waste.

Multiple surveys were conducted at various times at the RWILS facilities, but, due to the large area of these sites, these surveys appeared to be incomplete. According to the most complete survey conducted by the European Union under the Technical Assistance for the Commonwealth of Independent States (TACIS) project, only 2,970,000 $\mathrm{m}^{2}$ (297 ha) out of $10,780,000 \mathrm{~m}^{2}(1,078 \mathrm{ha}$ ) were surveyed, i.e., only $27 \%$ of the territory (Antropov et al. 2001). Therefore, accurate radiation hazard assessments of these waste localization sites are not available. According to the radiation monitoring data (Kireev et al. 2010) and joint studies conducted by the Institute of Geology of the National Academy of Science of Ukraine and the Institute for Radiological Protection and Nuclear Safety (IRSN) in France (Dewiere 2002), radionuclide transport with the underground water was recorded in such RWILS sites as the Red Forest site and the Yanov Station site. Consequently, so called radioactive waste interim localization facilities became secondary sources of environmental contamination.

The safest radioactive waste facilities are the RWDS, all three facilities of which were built in the period of time immediately following the ChNPP accident. The RWDS facilities were established for radioactive waste resulting from decontamination of the ChNPP units and the ChNPP industrial area.

Kompleksny RWDS (also known as the ChNPP Phase 3) was created in October of 1986 using unfinished structures of the radioactive waste storage facility that was part of the $5^{\text {th }}$ ChNPP Reactor Unit being built at that time (Fig. 3). The waste associated with the contaminated soil, metal structures, chunks of the roofing materials, and concrete from the ChNPP Fourth Reactor Unit was placed into metal $1.5-\mathrm{m}^{3}$ containers and those metal 
containers were installed into waterproof reinforced concrete tanks. The Kompleksny RWDS was shut down in 1988 . The total volume of the waste disposed of at the site is $26,200 \mathrm{~m}^{3}$ with the estimated activity of $74 \mathrm{TBq}$ (as of in 2000). The Kompleksny RWDS was decommissioned by filling it with sand and covering it with a 1-m thick clay layer topped with turf grass.

Monitoring wells were drilled along the perimeter of the Kompleksny RWDS to sample underground water. The ${ }^{90} \mathrm{Sr}$ concentration in the underground water at the site ranged from 170 to $2,700 \mathrm{~Bq} \mathrm{~m}^{-3}$ in 2009 , which was consistent with the recorded radionuclide content in the underground water throughout the ChNPP industrial site. There is currently no record of any potential radionuclide release from the Kompleksny RWDS. There are grounds to believe that this disposal site is periodically flooded with groundwater, the level of which may rise during years with a large amount of precipitation. The underground water monitoring during 25 years following the ChNPP accident shows a significant increase of the underground water level in the post-Chernobyl period. In addition, in the years with a high level of precipitation, the groundwater level increases by $0.5-0.9 \mathrm{~m}$.

Podlesny RWDS was specifically built in December of 1986 for disposal of the medium level and high level waste with the exposure dose rate ranging from 50 to $500 \mathrm{mSv}$ $\mathrm{h}^{-1}$ resulting from the decontamination of the ChNPP Reactor Units 3 and 4. The Podlesny RWDS is a concrete structure placed on a concrete $1.5-\mathrm{m}$ thick foundation. The walls of the vaults of this disposal site are 8 - $9 \mathrm{~m}$ high reinforced with a $4-5 \mathrm{~m}$ thick soil layer from the outside (Fig. 4 and 5). Only 2 vaults, Vault A-1 and Vault B-1, were actually utilized, but a total of 8 vaults were constructed. Vault B-1 received waste placed in $1.5 \mathrm{~m}^{3}$ metal containers and Vault A-1 received dumped non-containerized waste. The waste had not been preliminarily sorted. It contained chunks of the reactor graphite, fragments of reactor structures and other metal structures, chunks of fuel assemblies, and decontamination waste 
from ChNNP Reactor Units 3 and 4. The total volume of the waste disposed of at the Podlesny RWDS is estimated to be $3,960 \mathrm{~m}^{3}$ with the activity of $2.59 \mathrm{PBq}$ (MESU 2010). In November of 1988, the operation of the Podlesny RWDS was stopped and in 1990 it was decommissioned. The waste vaults were filled with $2,300-2,400 \mathrm{~m}^{3}$ of concrete and approximately $1,300-1,500 \mathrm{~m}^{3}$ of sand and gravel mixture. According to the 2009 radiation monitoring data, the ${ }^{90} \mathrm{Sr}$ content in groundwater monitoring wells ranged from 230 to $630 \mathrm{~Bq}$ $\mathrm{m}^{-3}$; practically not changing for the last few years.

Buryakovka RWDS is a subsurface disposal site located $10 \mathrm{~km}$ west of the city of Pripyat. It was commissioned in 1987 and it has been in operation since that time. The Buryakovka RWDS includes 30 trenches insulated with a 1-m thick clay layer. Twenty five trenches were completely filled with radioactive waste and decommissioned by filling them with sand topped with a 1-m thick clay layer and covered with turf grass (Fig. 6).

The waste at the Buryakovka RWDS is associated with contaminated machinery, metal and reinforced concrete structures, protective clothing, debris, etc. Prior to the $1990 \mathrm{~s}$, the criterion for the waste acceptance into the Buryakovka RWDS was that the external equivalent exposure dose not exceed $50 \mathrm{mSv} \mathrm{h}^{-1}$. On January 1, 1990, the acceptance criteria became more rigid: the maximum allowed exposure dose rate was decreased from $0.3 \mu \mathrm{Sv} \mathrm{h}^{-1}$ to $10 \mathrm{mSv} \mathrm{h}^{-1}$ and the content of alpha emitting radionuclides was no longer allowed to exceed $2 \%$ of the total activity. Only waste of the Chernobyl origin was accepted for the disposal. As of December 1, 2009, the volume of the disposed of waste at the Buryakovka RWDS was reported to be $601,358.9 \mathrm{~m}^{3}$ with the total activity of $2.48 \mathrm{PBq}$. According to the radiation monitoring data, the ${ }^{90} \mathrm{Sr}$ content in groundwater in the area of the Buryakovka RWDS ranges from 130 to $560 \mathrm{~Bq} \mathrm{~m}^{-3}$ without any recorded increase for the entire monitoring period. 


\section{RESOLVING RADIOACTIVE WASTE PROBLEMS IN THE ChEZ}

The data provided in the previous section show that safety of the ChEZ radioactive waste does not comply with modern standards and regulations. Since the waste was disposed of in an emergency mode, no accurate waste accounting was performed and comprehensive safety assessments of each waste storage or disposal facility will be associated with significant costs. Nevertheless, it will be reasonable to conduct such safety assessments for each radioactive waste disposal facility and for the entire $\mathrm{ChEZ}$ as a source of radioactive contamination because costs associated with building storage facilities for such large volumes of radioactive waste and its subsequent disposal will be much higher.

On August 19, 2009, the Cabinet of Ministers of Ukraine approved the Radioactive Waste Management Strategy of Ukraine (CMU 2009). The objective of the strategy is to complete development and assure an effective functioning of the comprehensive radioactive waste management system in Ukraine. The major focus areas identified in the Strategy underlie development and improvement of the current organizational, legal and industrial infrastructure for the radioactive waste management.

The implementation of the Strategy is planned for 50 years and consists of four phases. The Strategy aspects have been determined with great detail only for Phases 1 and 2 . The scope of work and amount of financing required for Phases 3 and 4 will be defined after completion of Phase 1 and partially Phase 2.

The objectives of Phase 1 are to improve the legislative and regulatory framework and national structure of the radioactive waste management, including its long-term storage and disposal; optimize the radioactive waste management funding mechanisms, develop new and upgrade the existing waste processing and conditioning systems at nuclear power plants, construct and commission safe short-lived low-level and medium-level waste storage 
facilities, retrieve and condition the existing commercial radioactive waste accumulated at the nuclear power plants storage facilities and provide for its safe final disposal, and select a site for construction of the facility for disposal of high level and long-lived low-level and medium-level waste in deep geological repositories.

During Phase 1 and in accordance with the National Radioactive Waste Management Program in Ukraine (VRU 2009), new amendments to the legislative regulations were issued regarding funding of the radioactive waste management system. The first National Radioactive Waste Management Fund was established and the system for collecting fees from radioactive waste generating sites was introduced. The construction of the radioactive waste management Vektor Complex is in progress in the ChEZ (Fig. 7).

With financial support from the European Commission, design and construction of a large-scale solid radioactive waste processing complex plant [Industrial Complex for Solid Radioactive Waste Management (ICSRM)] were completed at the ChNPP. The plant includes three solid radioactive waste facilities combined in a single cycle. The site is intended for receipt, processing and/or disposal of the solid radioactive waste accumulated during the ChNPP operation and the waste resulted from its decommissioning, as well as the radioactive waste associated with operation of the Shelter facility. The site ICSRM provides for the following:

- Interim storage of low level and medium level waste and high level waste (waste packages and a service filling life of 30 years, followed by 300 years of national monitoring after its closure) designed and built in the existing liquid and solid radioactive waste storage building at the ChNPP industrial site;

- System for retrieval of solid radioactive waste of all categories from the existing solid radioactive waste storage facility located in the solid radioactive waste storage facility building at the ChNPP site; 
- Plant for sorting solid radioactive waste of all categories and conditioning low and medium level solid waste with the total throughput of $20 \mathrm{~m}^{3}$ of unprocessed waste per day, including the incineration system for processing solid radioactive waste at $50 \mathrm{~kg} \mathrm{~h}^{-1}$ and liquid radioactive waste at $10 \mathrm{~kg} \mathrm{~h}^{-1}$; the grouting facility at $10 \mathrm{~m}^{3} \mathrm{~d}^{-}$ ${ }^{1}$, the low and medium-level legacy waste and high level waste packaging facility at $1.5 \mathrm{~m}^{3} \mathrm{~d}^{-1}$, and the low and medium-level legacy waste and high-level waste interim storage facility with the capacity of $3,500 \mathrm{~m}^{3}$ and the service life of $30 \mathrm{y}$;

- A specially equipped subsurface low and medium level short-lived solid radioactive waste storage facility with the capacity of $55,000 \mathrm{~m}^{3}$ of waste packages and service life of $30 \mathrm{y}$ for filling up the facility followed by $300 \mathrm{y}$ of the national monitoring after its closure; the facility is located within the Vektor Complex.

The following activities are planned for Phase 2 intended to continue for up to 30 years:

- Complete work on disposition of hazardous waste storage facilities associated with the ChNPP accident, as well as hazardous waste storage facilities at the specialized local facilities of the State Enterprise "Radon;"

- Continue retrieval and conditioning of commercial radioactive waste from the NPP storage facilities and radioactive waste resulting from decommissioning of power reactors of the nuclear power plants, specifically, of the ChNPP, and provide for its final disposal;

- Design, construct, and commission the high-level waste storage facility in stable geological repositories;

- Develop technologies and equipment and perform activities on retrieval of radioactive waste from the Shelter Facility. 
The following activities are planned for Phase 3 intended to continue for 12 years:

- Continue operation of the radioactive waste conditioning, packaging, and storage facilities;

- Complete major activities on disposal of radioactive waste resulting from the ChNPP decommissioning and conversion of the Shelter facility into an environmentally safe system;

- Perform activities on remediation of the contaminated areas.

The estimated cost for implementation of this strategic program is approximately $\$ 4.5$ billion (35,783.8 million Ukrainian Grivnas) (CMU 2009). The funding will be provided by the Federal budget, National Radioactive Waste Management Fund, domestic radioactive waste generating sites, and international technical assistance.

\section{CONCLUSIONS}

The brief overview of the radioactive waste issues in the ChEZ presented in this article demonstrates that management of radioactive waste resulting from a beyond-designbasis accident at a nuclear power plant becomes the most challenging and the costliest effort during the mitigation and remediation activities. The costs of these activities are so high that the provision of radioactive waste final disposal facilities compliant with existing radiation safety requirements becomes an intolerable burden for the current generation of a single country, Ukraine.

The nuclear accident at the Fukushima-1 NPP strongly indicates that accidents at nuclear sites may occur in any, even in a most technologically advanced country, and the Chernobyl experience shows that the scope of the radioactive waste management activities associated with the mitigation of such accidents may exceed the capabilities of a single 
country. Development of a special international program for broad international cooperation in accident related radioactive waste management activities is required to handle these issues. It would also be reasonable to consider establishment of a dedicated international fund for mitigation of accidents at nuclear sites, specifically, for handling radioactive waste problems in the ChEZ. The experience of handling Chernobyl radioactive waste management issues, including large volumes of radioactive soils and complex structures of fuel containing materials can be fairly useful for the entire world's nuclear community and can help make nuclear energy safer.

Acknowledgments - The authors would like to thank Ines Triay, Yvette Collazo, Kurt Gerdes, and Ana Han for their support of the U.S. Department of Energy Office of Environmental Management's International Cooperative Program with IRL. The authors would like to express their appreciation to the National Agency of Ukraine for the Chernobyl Exclusion Zone Management for their support of this article. The authors would also like to express their gratitude to Tatyana Albert (Thomas E. Albert and Associates, Inc.) for translating documents and reports prepared at SRNL and IRL and Yasmine Elraheb and Jennifer Grant for their editorial contributions.

Disclaimer - This manuscript has been co-authored by Savannah River Nuclear Solutions, LLC under Contract No. DE-AC09-08SR22470 with the U.S. Department of Energy. The United States Government retains and the publisher, by accepting this article for publication, acknowledges that the United States Government retains a non-exclusive, paid-up, irrevocable, worldwide license to publish or reproduce the published form of this work, or allow others to do so, for United States Government purposes. Mention of trade names or 
commercial products does not constitute endorsement or recommendation for use by the authors or their corresponding organizations.

\section{REFERENCES}

Antropov VM, Bugai DA, Dutton LM, Gerchikov MY, Kennett EJ, Ledenev AI, Novikov AA, Rudko V, Ziegenhagen J. Review and analysis of solid long-lived and high level radioactive waste arising at the Chernobyl nuclear power plant and the restricted zone. DG Environment Project; No B7-5350/99/51983/MAR/C2; Chernobyl, Ukraine; 2001.

Cabinet of Ministers of Ukraine (CMU). Radioactive waste management strategy in Ukraine. Directive of the Cabinet of Ministers of 19 August 2009; \# 990-g; 2009.

Chernobyl Nuclear Power Plant (ChNPP). "Shelter” object safety analysis report; SIP-P-PM22-460-SAR-124-01. Available at: http://www.chnpp.gov.ua/. (Accessed 15 June 2011); 2006.

Chernobyl Nuclear Power Plant (ChNPP). "Shelter” object safety status report; SIP-P-PM22-460- SAR-124-05. Available at: http://www.chnpp.gov.ua/. (Accessed 15 June 2011); 2008.

Dewiere L. Validating a pilot plan in the Chernobyl exclusion area by means of experiments. Report 2000-2001. Institut de Radioprotection et de Surete Nucleaire (IRSN). DPRE/SERGD/02-36, Appendix VI-b; Fontenay-Aux-Rose, Rapport; 2002.

International Atomic Energy Agency (IAEA) - Workshop. Proskura NI, ed. State radioactive waste storage facility creation strategy in geological formations. Kiev, Ukraine; 2006. 
International Atomic Energy Agency (IAEA). Estimation of global inventories of radioactive waste and other radioactive materials. IAEA-Tecdoc-1591; ISBN 978-92-0-1056085; ISSN 1011-4289, Vienna; 2008.

Kireev CI, Bespaly MV, Evseenko MG, Kedranovsky MV, Godun BO, Omelyanenko OI, Mazay SM, Vlasenko GM, Tepikin VE, Zholobov AG, Pazenko OV, Motuz MO, Mischenko OG. Report on activities of the DSNVP Ecocenter for 2009, Chernobyl, Ukraine; 2010.

Ministry of Emergency Situations of Ukraine (MESU), State corporation Ukrradon. National register of the radioactive waste. National register of radioactive waste disposal and interim storage sites. Report for 2009. Kiev, Ukraine; 2010.

Ministry of Health of Ukraine (MHU), the National Commission for Radiation Safety of the Ukrainian Population. Radiation safety regulations. Kiev, Ukraine; 1997.

Verkhovna Rada of Ukraine (VRU). Law of Ukraine: On national program for decommissioning of the chernobyl npp and conversion of the shelter facility into an environmentally safe system. Bulletin of the Verkhovna Rada of Ukraine, No.24, Article 300; Kiev, Ukraine; 2009. 


\section{FIGURE CAPTIONS}

Fig. 1. Estimated ${ }^{90} \mathrm{Sr}$ washout and seepage into the Pripyat River in $1989-2009$ (Kireev et al. 2010).

Fig. 2. Locations of Selected RWILS Sites and the Red Forest RWILS Site Schematics (Antropov et al. 2001). A) Layout of trenches at the Red Forest RWILS (T=trenches, $\mathrm{B}=$ mounds). B) Aerial photo of the ChNPP area indicating locations of the RWILS.

Fig. 3. Kompleksny RWDS Site (known as ChNPP Phase 3. A) Cross section of the Kompleksny RWDS. B) Location of the Kompleksny RWDS.

Fig. 4. Location and Layout of the Podlesny RWDS. A) Podlesny RWDS layout (soil sampling locations are shown in green and groundwater monitoring wells are shown in blue). B) Location of the Podlesny RWDS.

Fig. 5. Current view of the Podlesny RWDS (after decommissioning). A) Outside view of Vault A-1. B) Inside view of Vault A-1.

Fig. 6. Buryakovka RWDS layout and configuration. A) Layout. B) Location. C) Aeral photograph. D) Cross-sectional view of the waste trench.

Fig. 7. Aerial view of the Vektor complex site. 1) Administration Building and Cafeteria. 2) Change Room and a Laboratory. 3) Entry Control Point Building with Health Physics Control. 4) Technological Building (Waste Sorting and Repackaging). 5) Solid Radioactive Waste Storage Facility (Low and Medium Level Waste with Short-Lived Radionuclides) for ChNPP waste (an industrial facility for solid radioactive waste management), Lot 3 -ChNPP. 6) Car wash for specialized vehicles. 7) Fire Department. 


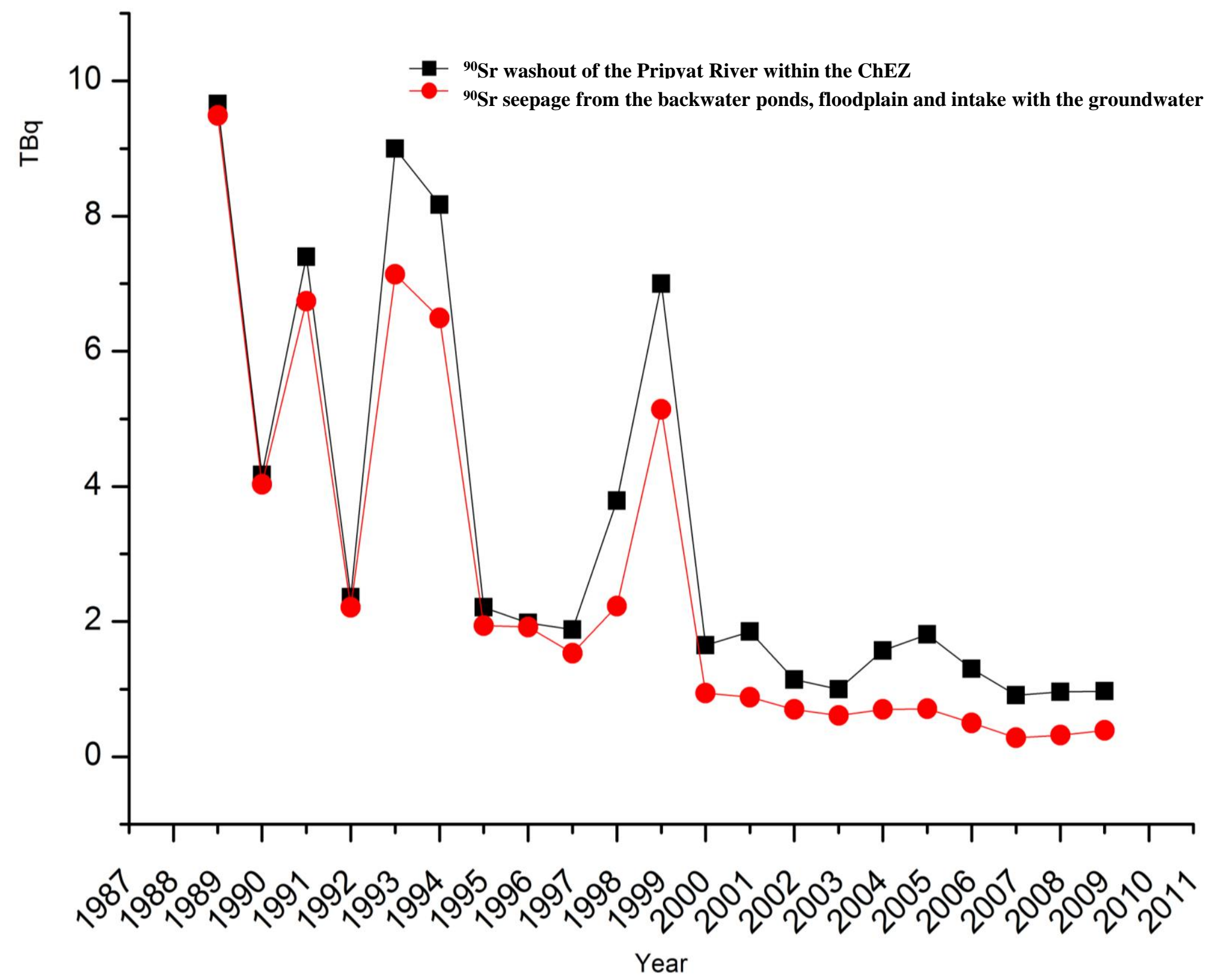




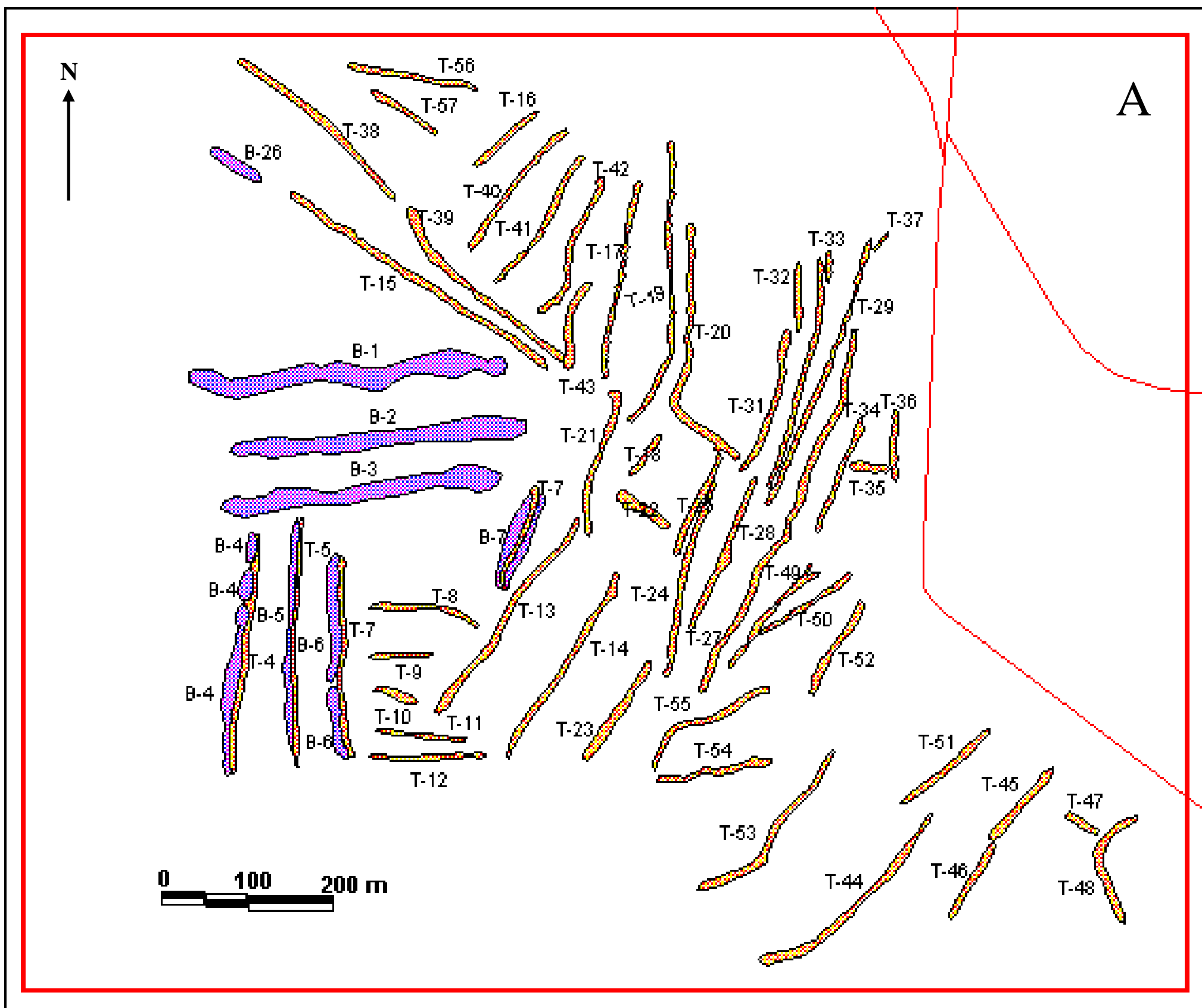




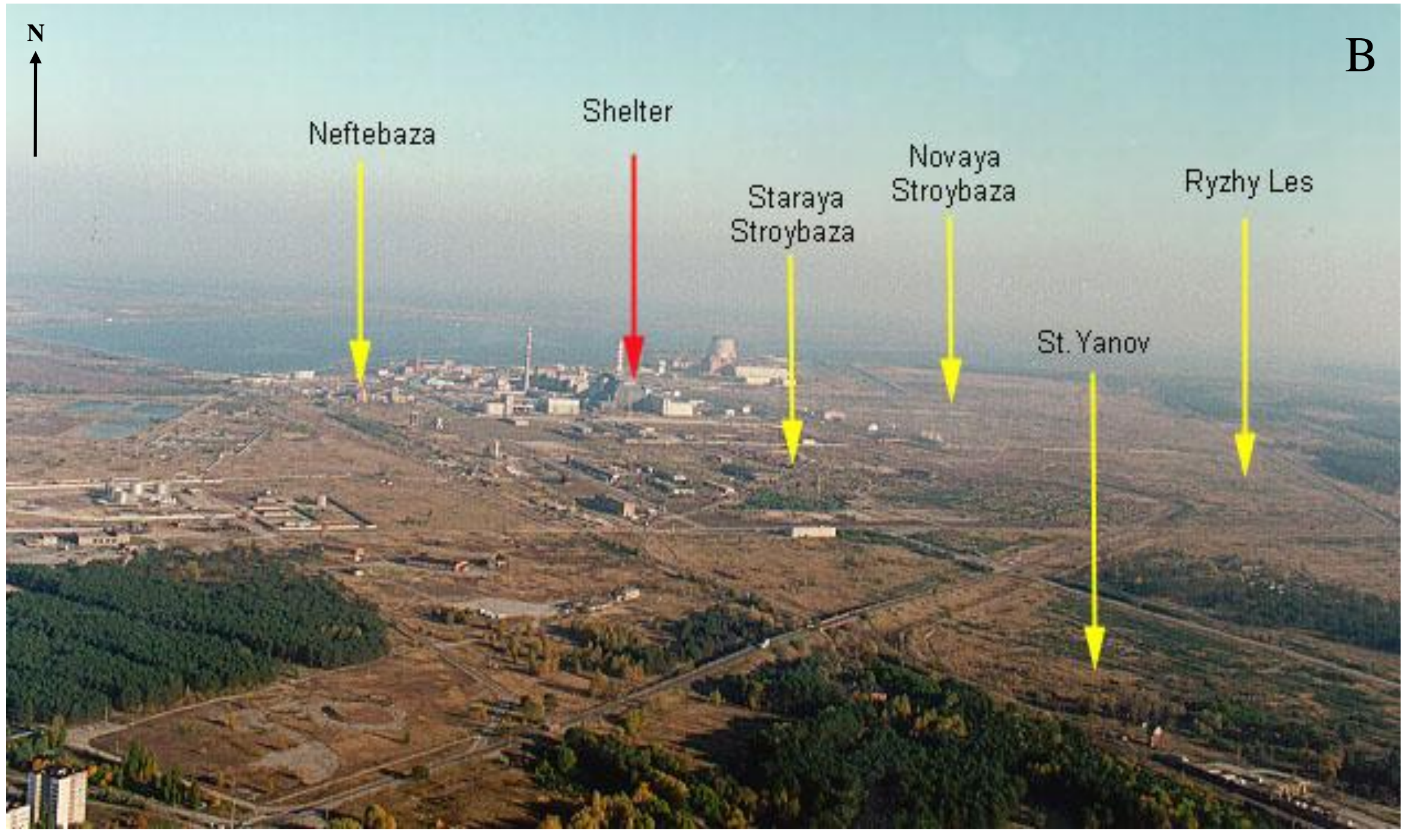




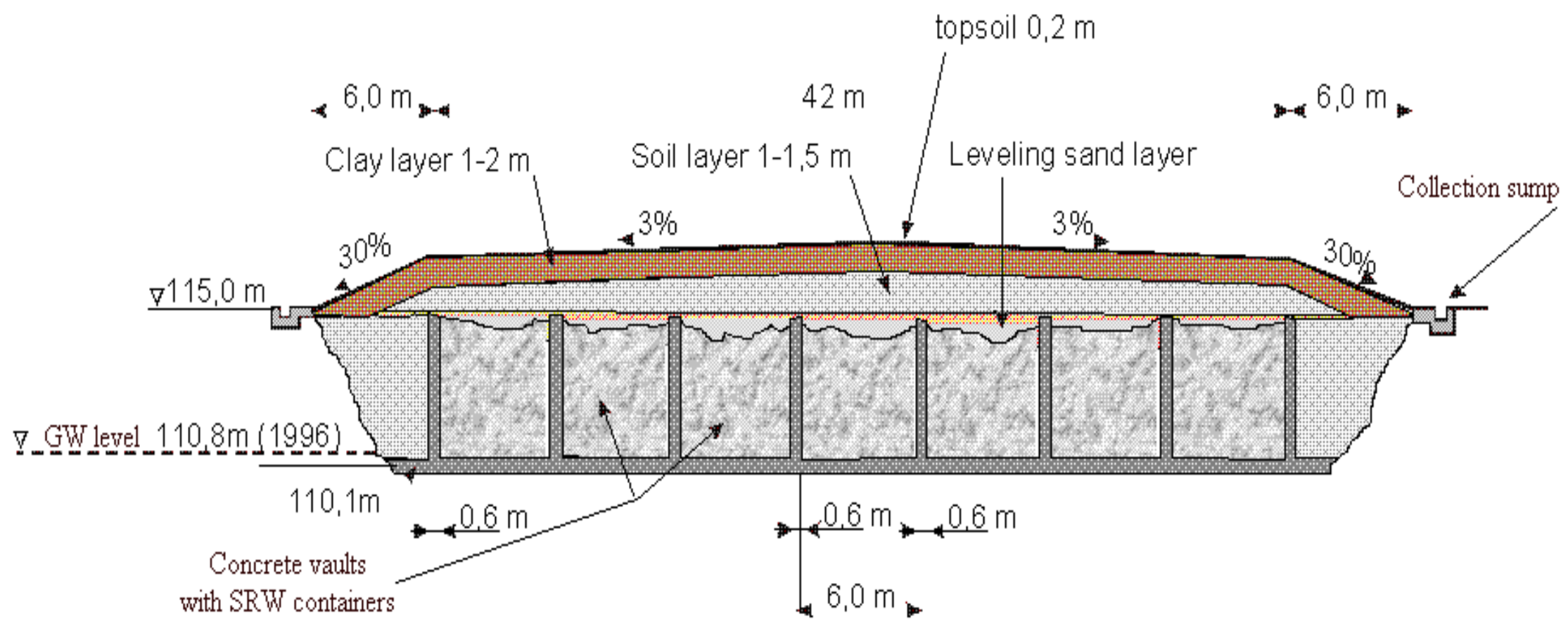

A 


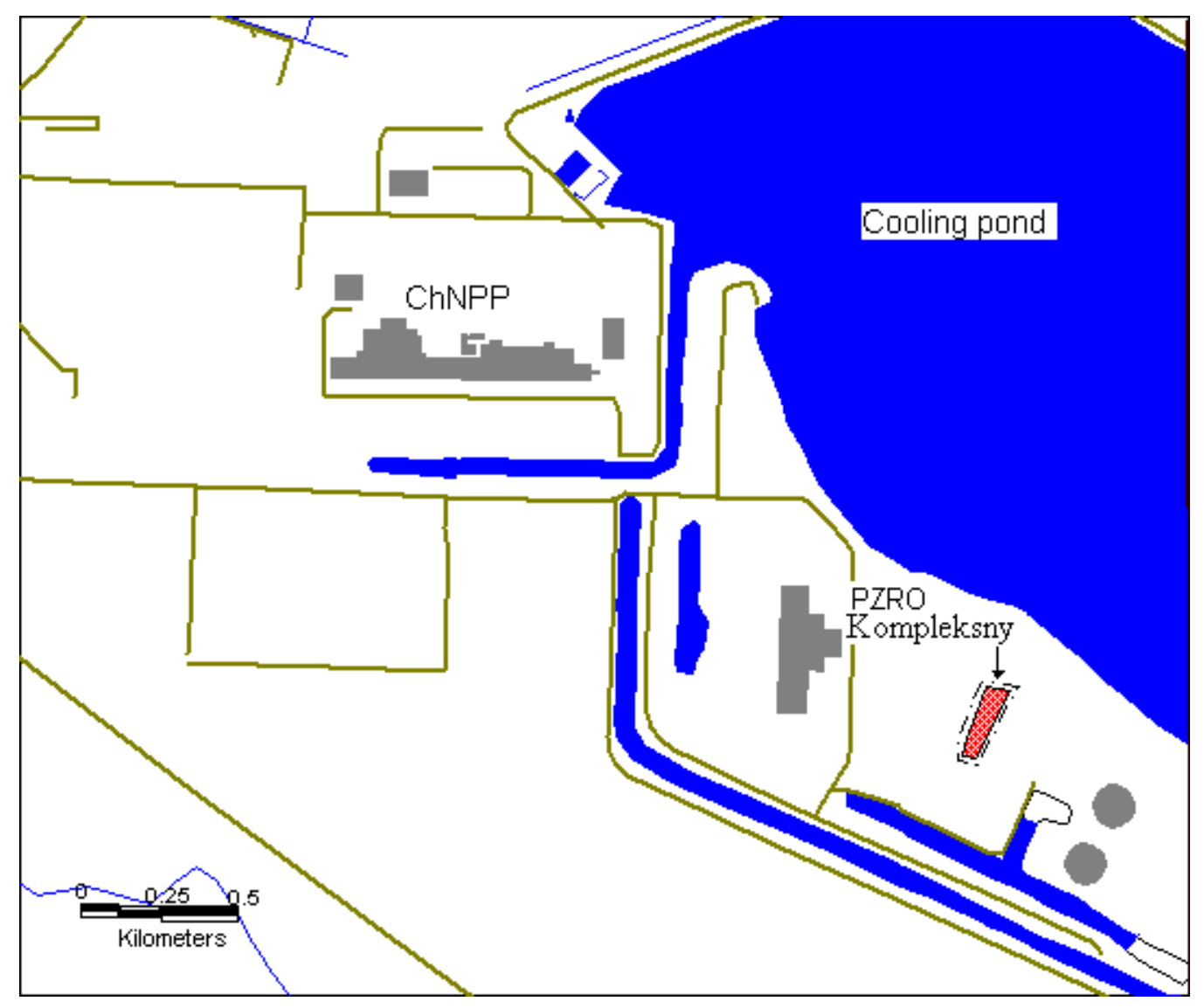

B 


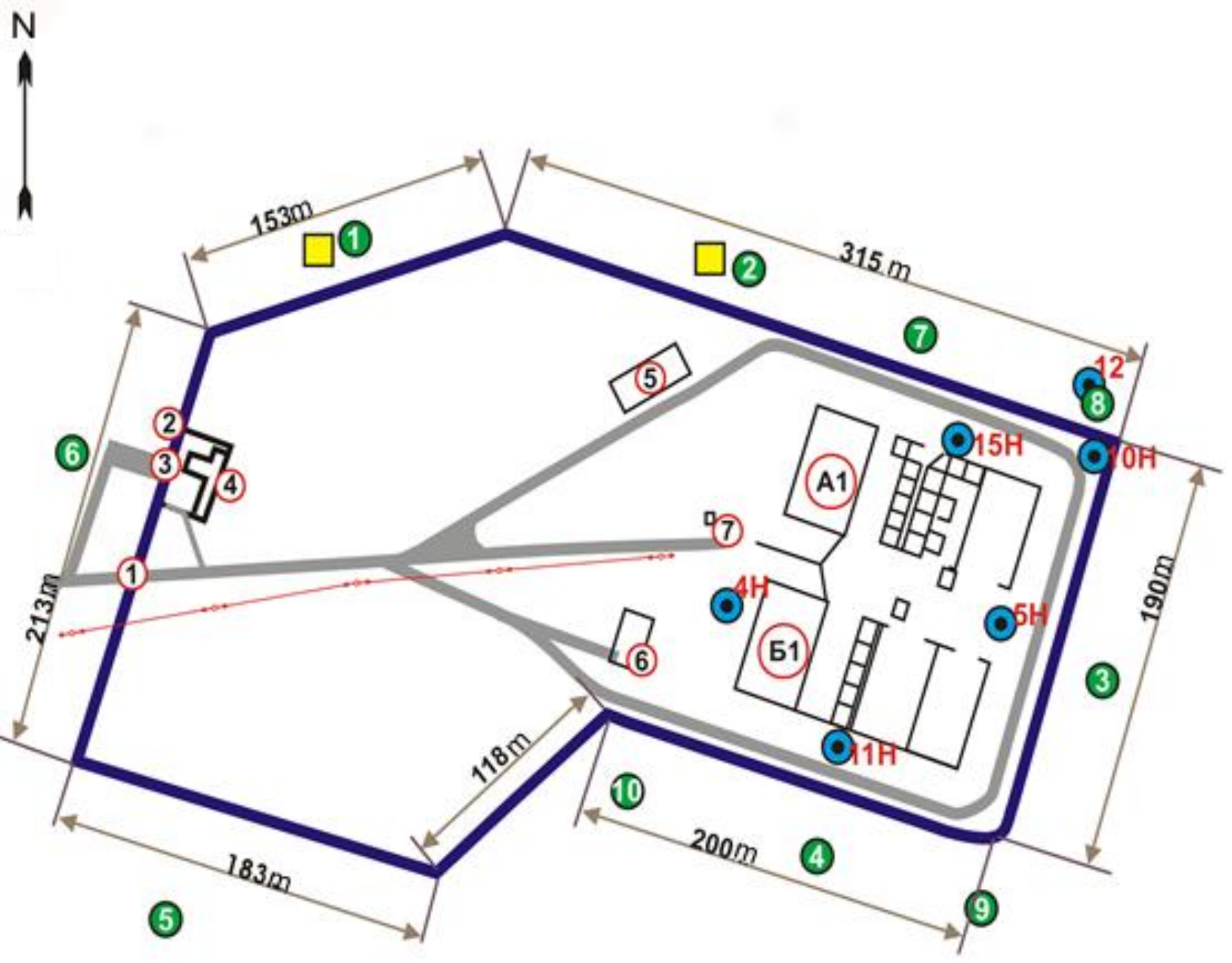

\section{Legend}

(1) Central gate

(2) Sanitary inspection

(3) Check point

(4) Sanitary inspection

room

(5) Car washing

(6) Control center

(7) $\begin{gathered}\text { Transformer } \\ \text { substation }\end{gathered}$

A1) Vault RW A-1

(51) Vault RW B-1

- Line electric power

\section{Fencing}

(7) Soil sampling point

5H Monitoring Wells

Sample vials atmospheric $\square$ precipitation 


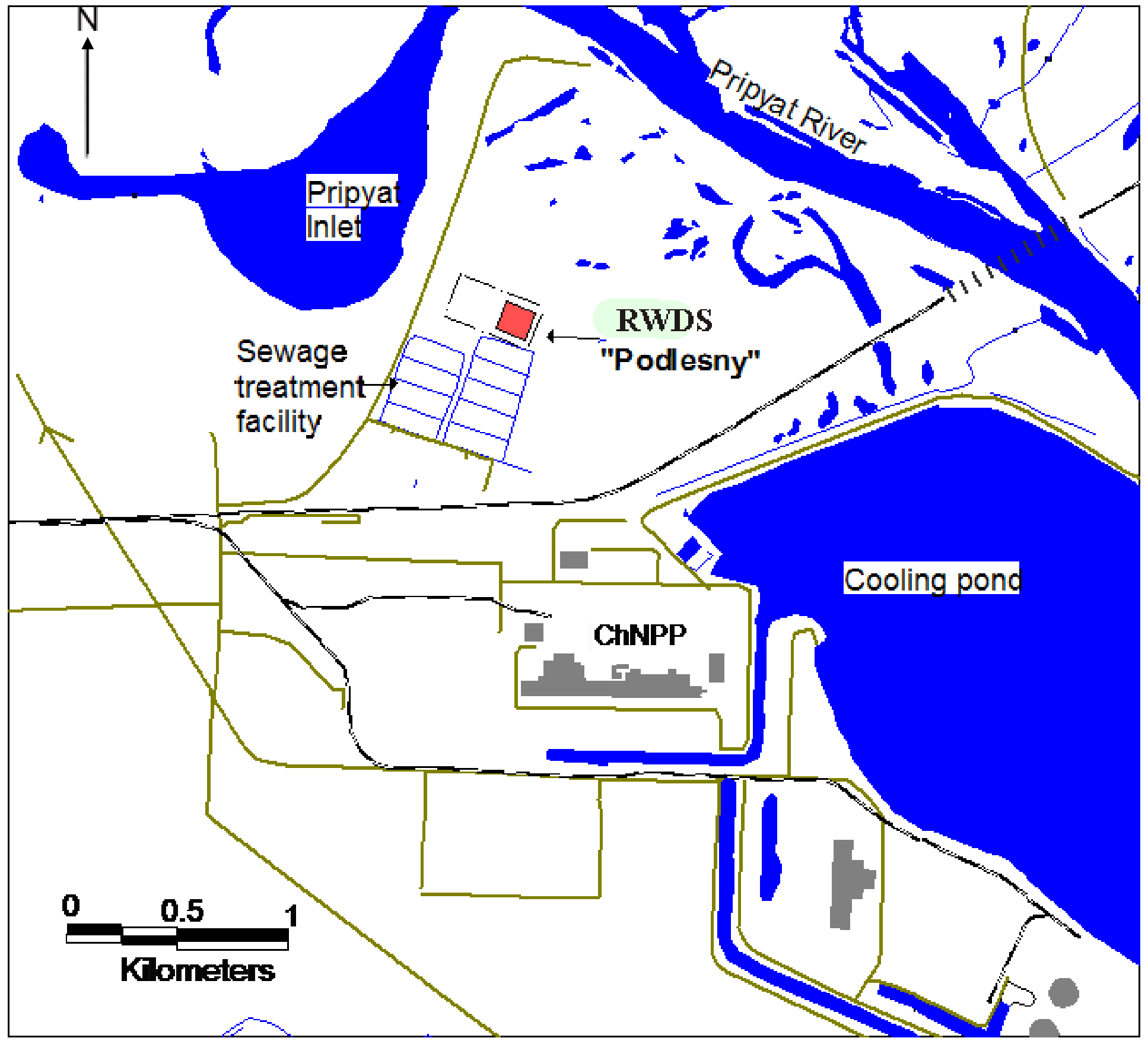


Figure 5

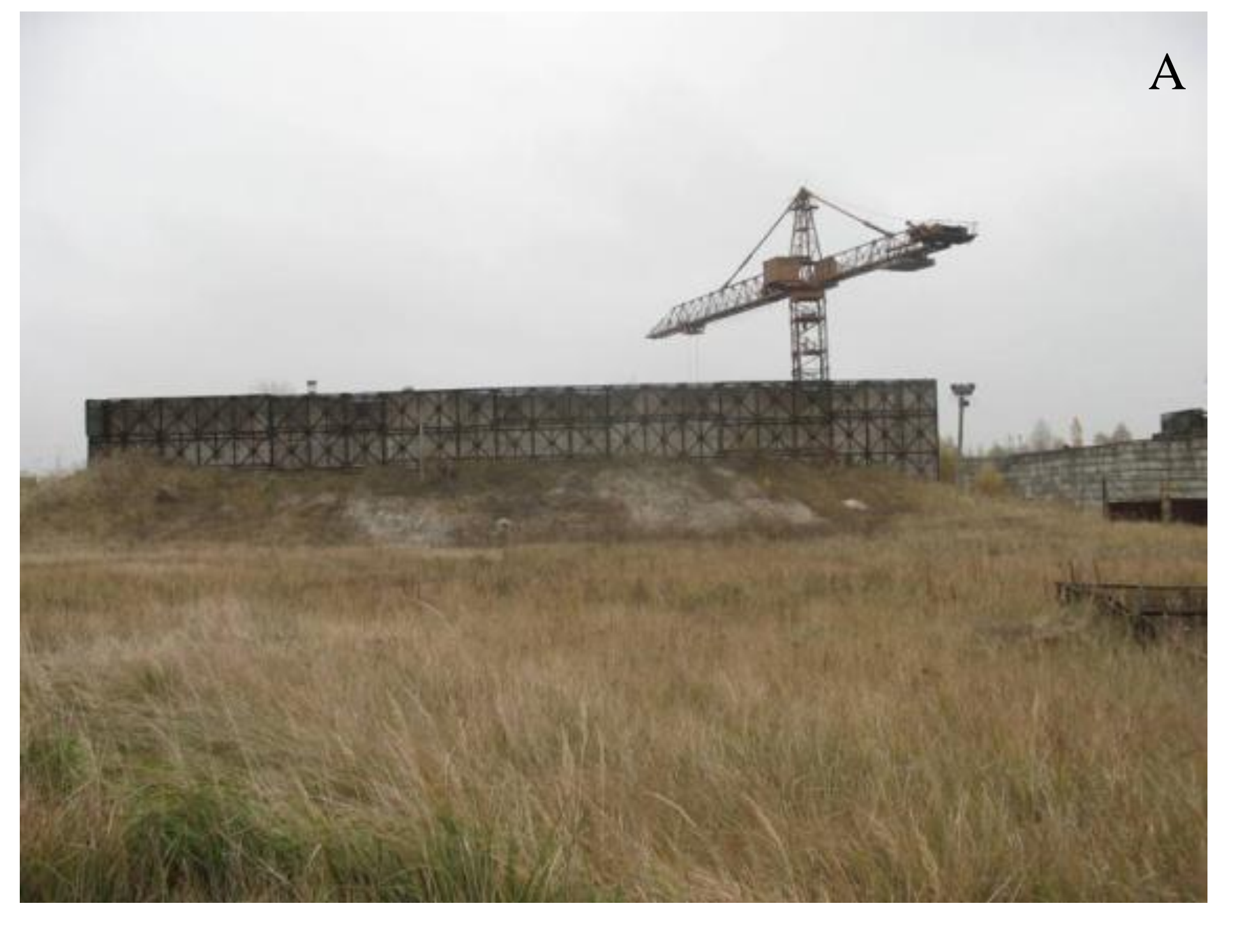

A

\author{
5
}

.
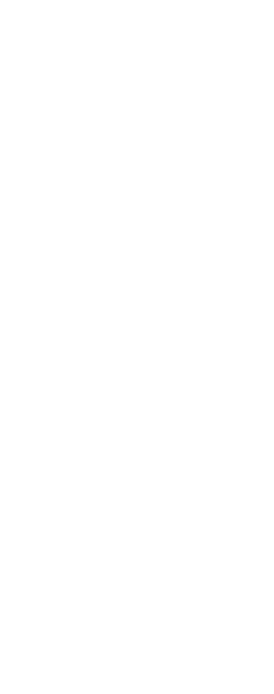
B

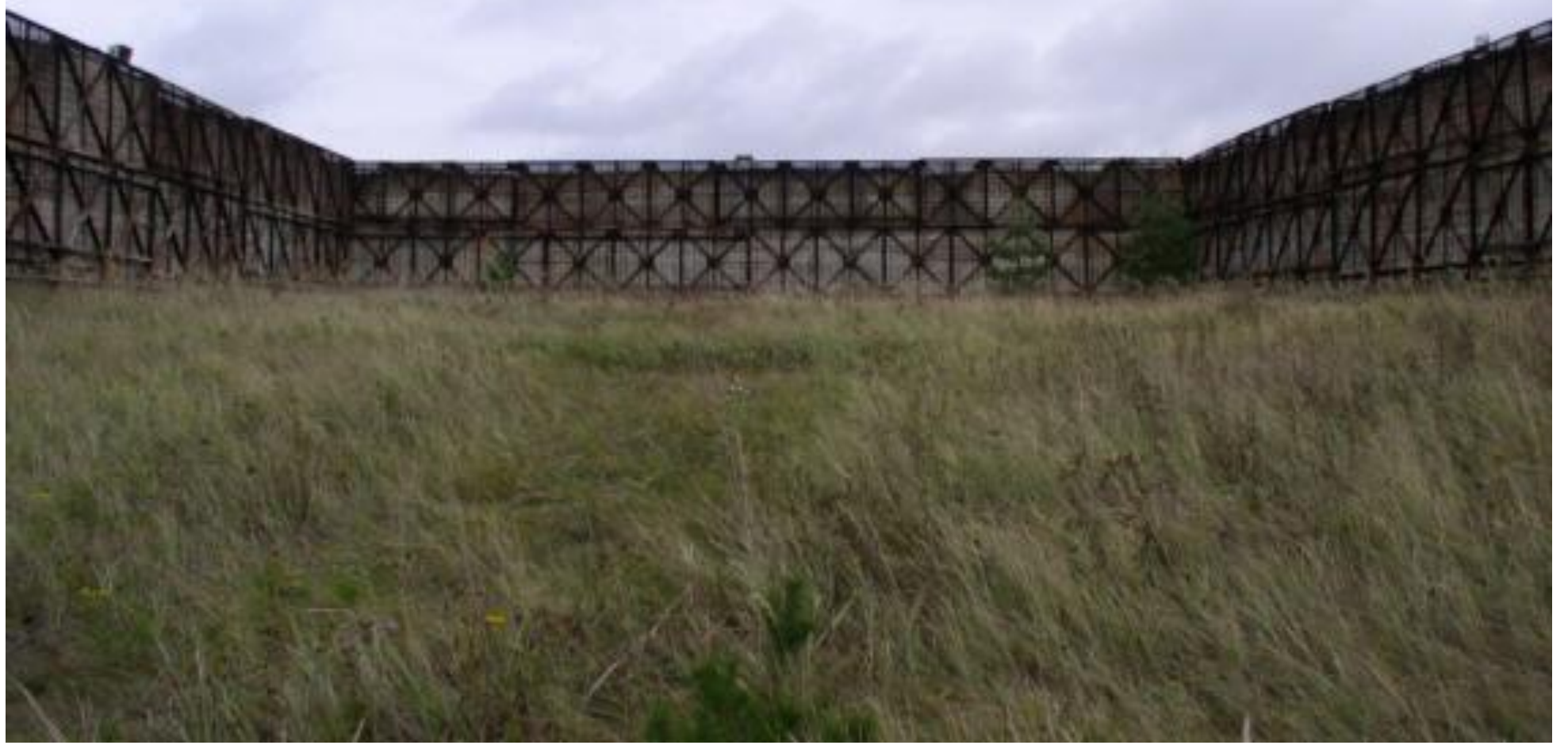




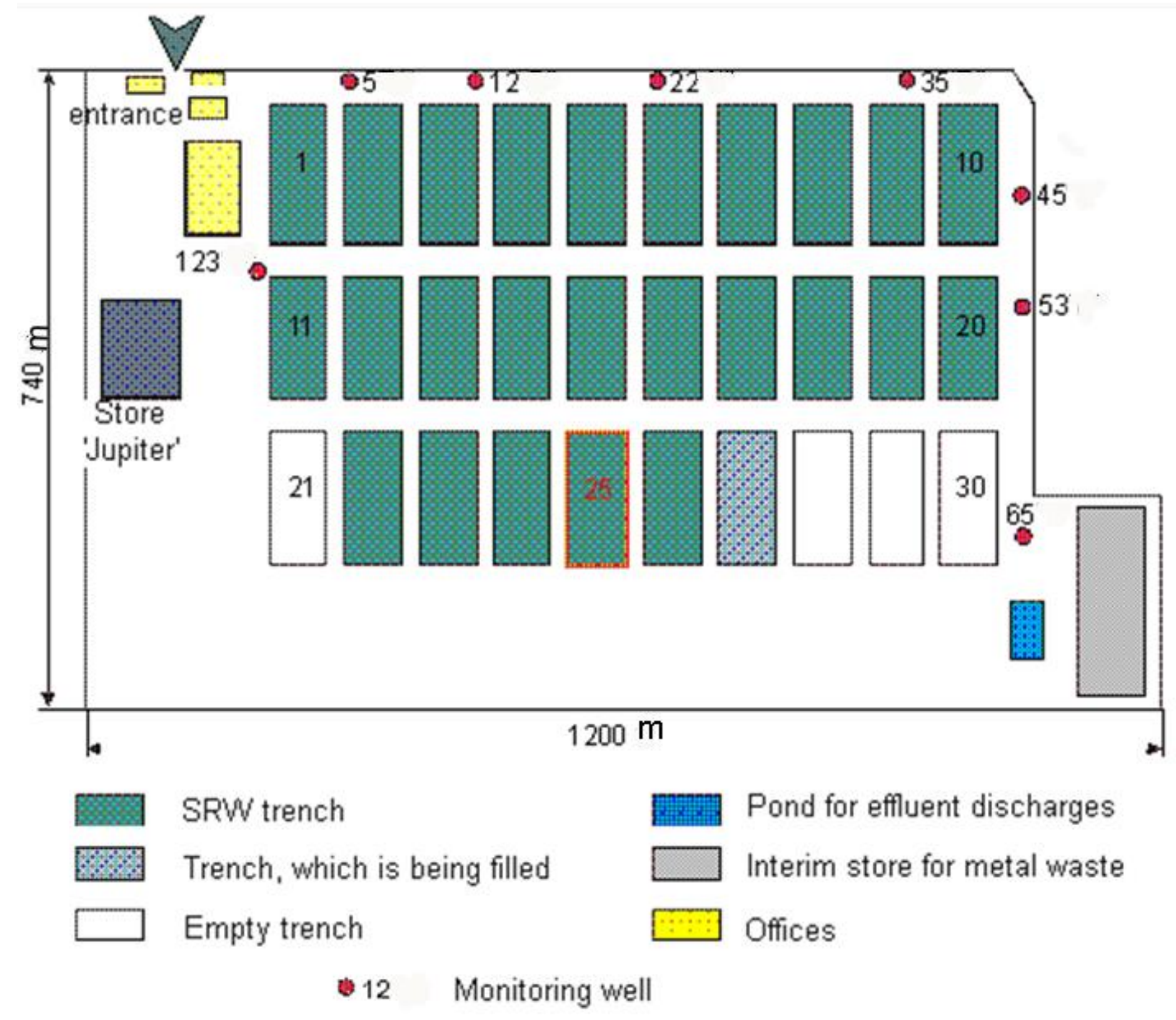

1 


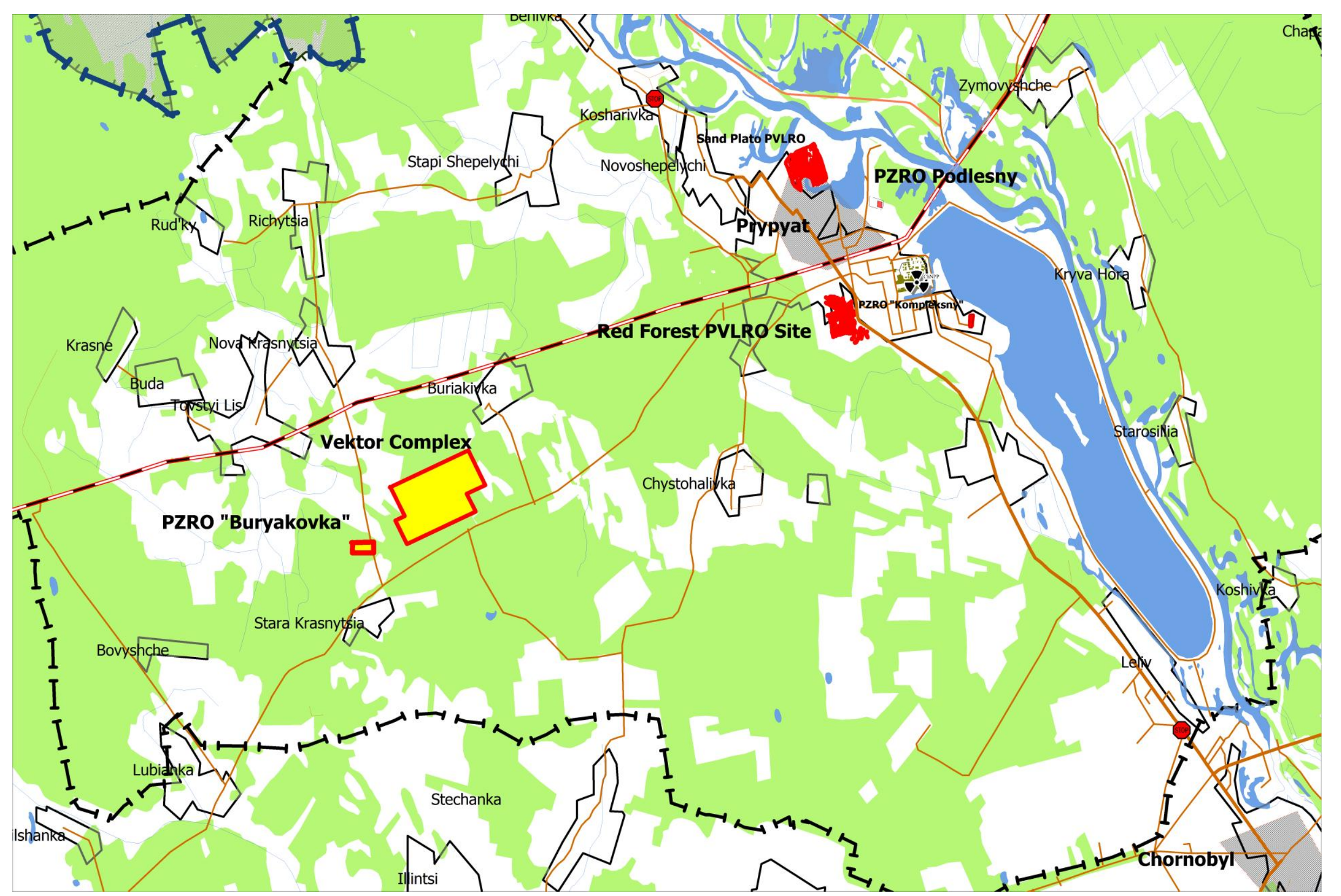




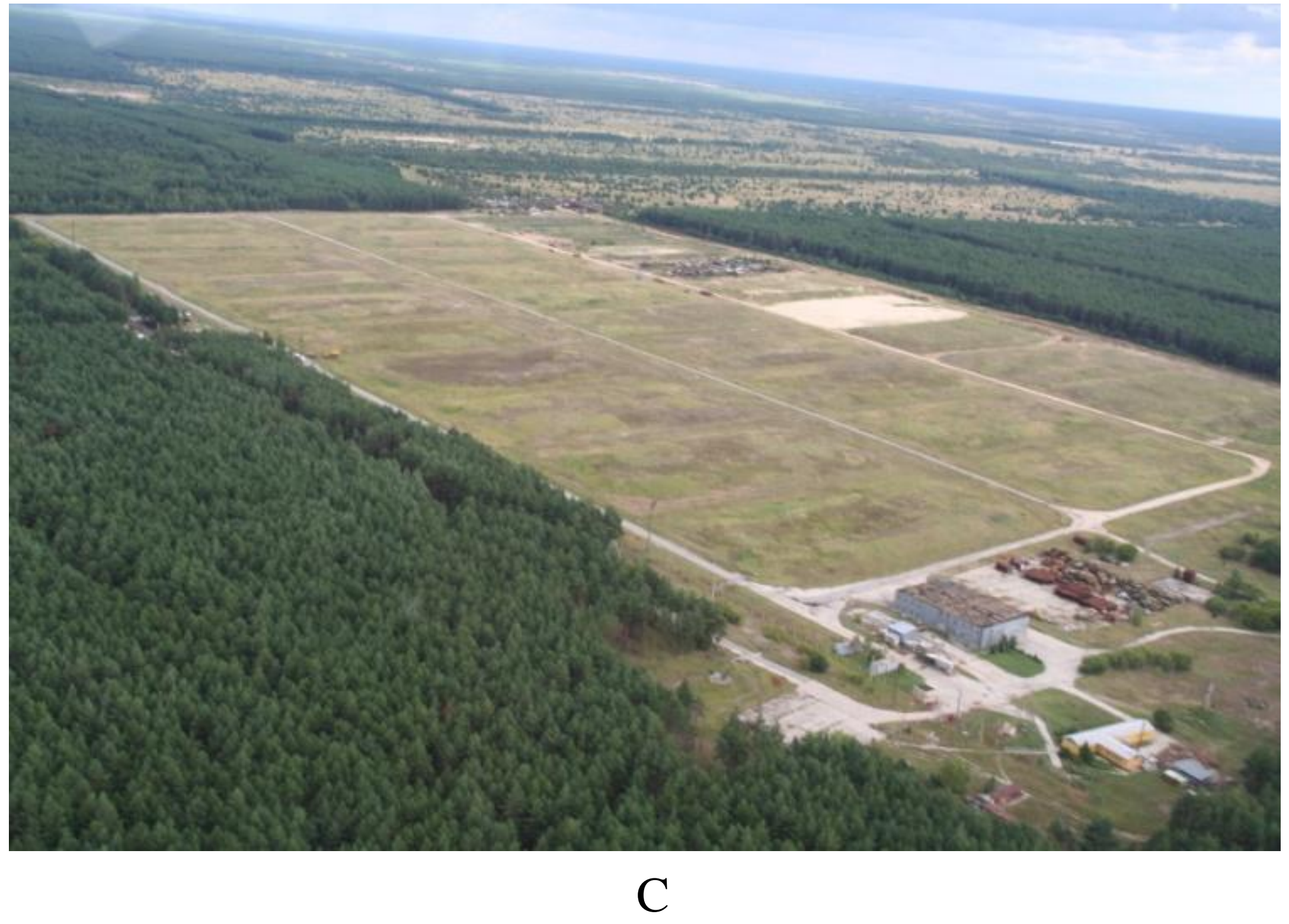




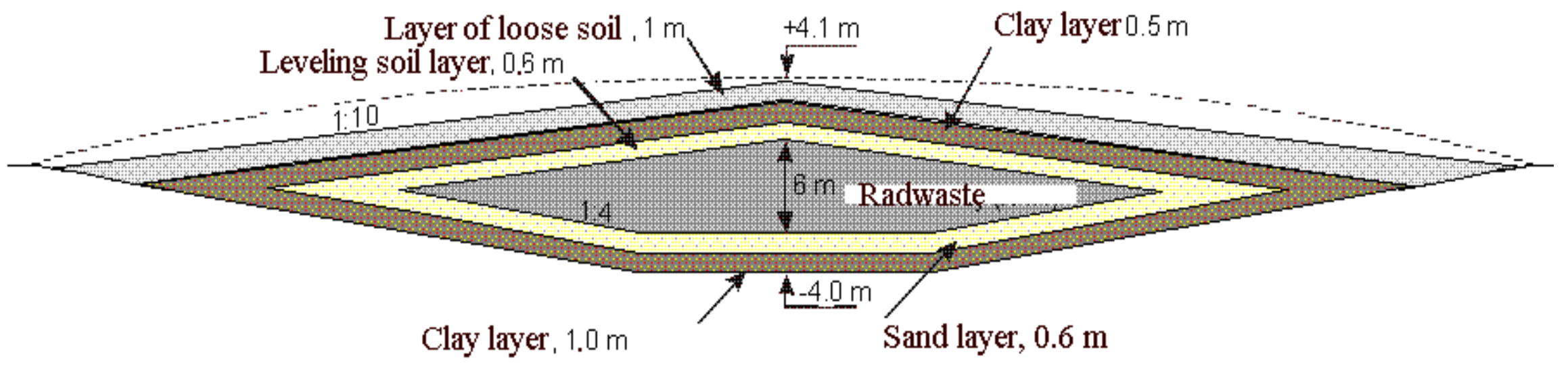

$21.4 \mathrm{~m}$

$16 \mathrm{~m}$

$21.4 \mathrm{~m}$

D 


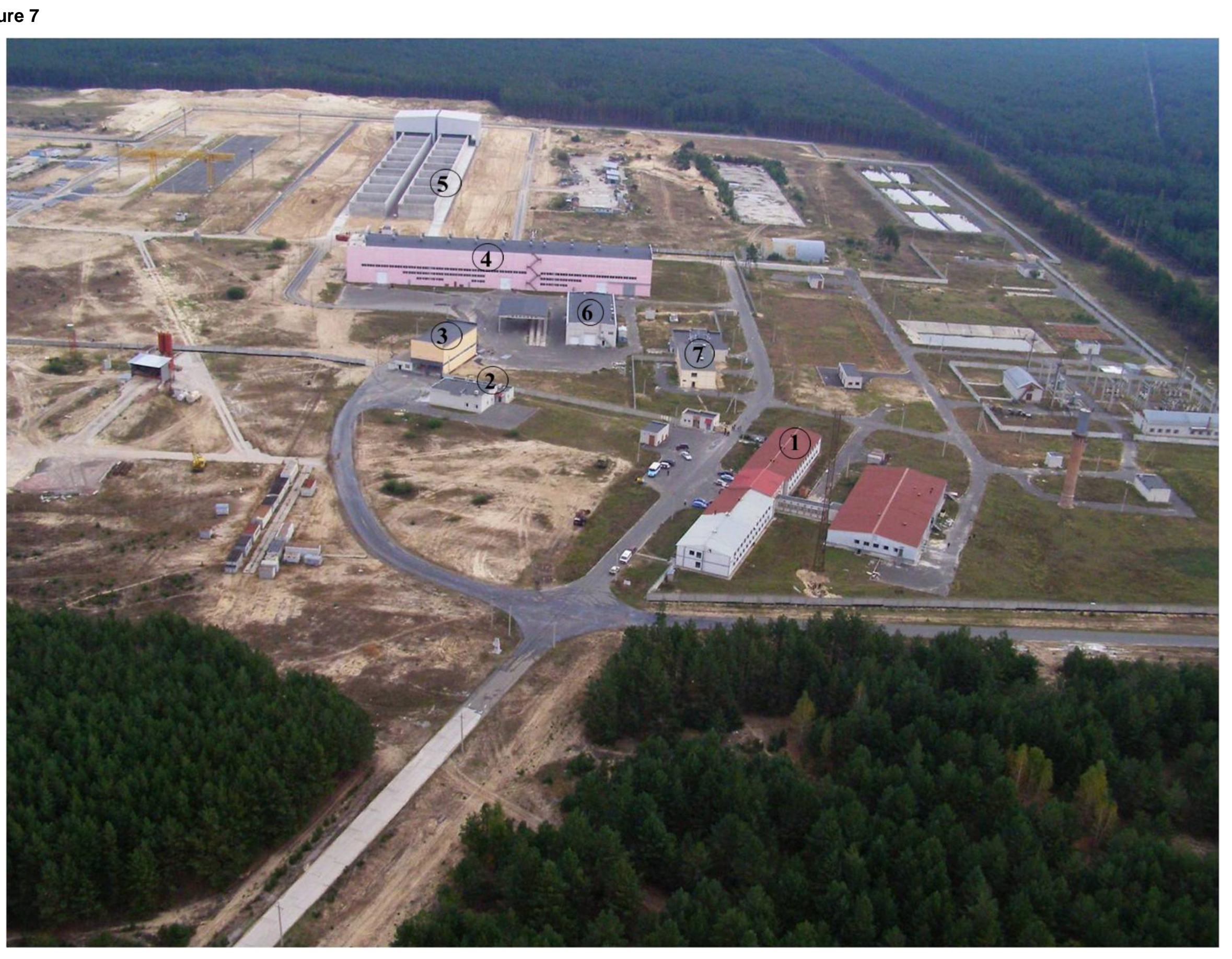

Figure 7

$-2$

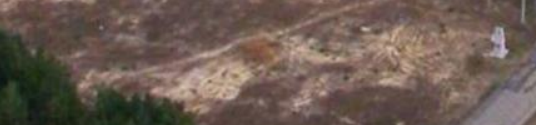
tet.

.

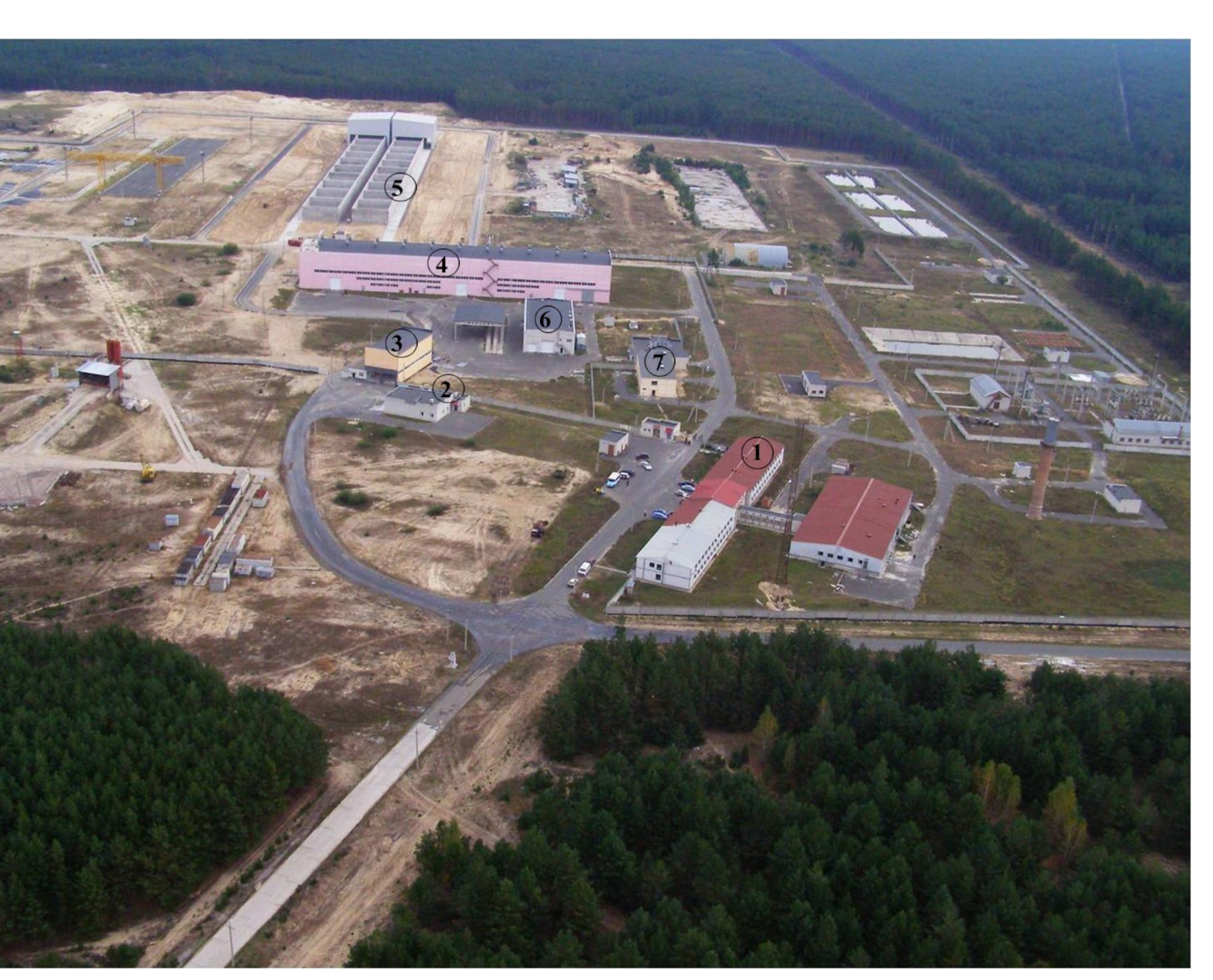

. 
Table 1. Radioactive waste at the Ukrainian nuclear power plants (as of October 1, 2008) (MESU 2010).

\begin{tabular}{|c|c|c|}
\hline NPP & Type of radioactive waste & $\begin{array}{l}\text { Volume of radioactive } \\
\text { waste, } \mathbf{m}^{3}\end{array}$ \\
\hline \multirow[t]{6}{*}{ Zaporozhskaya NPP } & Salt plav ${ }^{a}$ & $5,410.0$ \\
\hline & Evaporated liquid waste & $2,239.0$ \\
\hline & Sorbents, oils, sludge & 350.0 \\
\hline & $\begin{array}{l}\text { Solid radioactive waste Group } 1 \\
\text { (LLW) }\end{array}$ & $7,944.1$ \\
\hline & $\begin{array}{l}\text { Solid radioactive waste Group } 2 \\
\text { (MLW) }\end{array}$ & 639.2 \\
\hline & $\begin{array}{l}\text { Solid radioactive waste Group } 3 \\
\text { (HLW) }\end{array}$ & 86.5 \\
\hline \multirow[t]{6}{*}{ Rovenskaya NPP } & Salt plav & 876.9 \\
\hline & Evaporated liquid waste & $4,773.0$ \\
\hline & Sorbents, oils, sludge & 525.3 \\
\hline & $\begin{array}{l}\text { Solid radioactive waste Group } 1 \\
\text { (LLW) }\end{array}$ & $5,631.0$ \\
\hline & $\begin{array}{l}\text { Solid radioactive waste Group } 2 \\
\text { (MLW) }\end{array}$ & 1202.9 \\
\hline & $\begin{array}{l}\text { Solid radioactive waste Group } 3 \\
(\mathrm{HLW})\end{array}$ & 63.6 \\
\hline \multirow[t]{6}{*}{ Khmelnitskaya NPP } & Salt plav & 785.6 \\
\hline & Evaporated liquid waste & 476.7 \\
\hline & Sorbents, oils, sludge & 155.6 \\
\hline & $\begin{array}{l}\text { Solid radioactive waste Group } 1 \\
\text { (LLW) }\end{array}$ & $4,001.1$ \\
\hline & $\begin{array}{l}\text { Solid radioactive waste Group } 2 \\
\text { (MLW) }\end{array}$ & 114.1 \\
\hline & $\begin{array}{l}\text { Solid radioactive waste Group } 3 \\
(\mathrm{HLW})\end{array}$ & 8.8 \\
\hline \multirow[t]{6}{*}{ South Ukrainskaya NPP } & Salt plav & 0 \\
\hline & Evaporated liquid waste & $2,903.0$ \\
\hline & Sorbents, oils, sludge & 228.1 \\
\hline & $\begin{array}{l}\text { Solid radioactive waste Group } 1 \\
\text { (LLW) }\end{array}$ & $15,985.8$ \\
\hline & $\begin{array}{l}\text { Solid radioactive waste Group } 2 \\
\text { (MLW) }\end{array}$ & 565.8 \\
\hline & $\begin{array}{l}\text { Solid radioactive waste Group } 3 \\
\text { (HLW) }\end{array}$ & 13.3 \\
\hline
\end{tabular}

\footnotetext{
a A special type of liquid radioactive waste associated with reactors with so called "boron adjustment". This waste has a high density $\left(2,000-2,100 \mathrm{~kg} \mathrm{dm}^{-3}\right)$, it contains up to $310 \mathrm{~g} \cdot \mathrm{kg}^{-1}$ of $\mathrm{H}_{3} \mathrm{~B}_{3}$ and $180-220 \mathrm{~g} \mathrm{~kg}^{-1}$ of $\mathrm{Na}+$. The specific activity of this waste is up to $111 \mathrm{MBq}$.
} 
Table 2. Radioactive waste stored at the Ukrainian State Corporation Radon Storage Facilities as of January 1, 2010 (exclusive of sealed sources of ionizing radiation) (MESU 2010).

\begin{tabular}{lrrrr}
\hline Names of the facility & \multicolumn{2}{c}{$\begin{array}{c}\text { Low and medium level } \\
\text { solid waste }\end{array}$} & \multicolumn{2}{c}{$\begin{array}{c}\text { Low and medium level } \\
\text { liquid waste }\end{array}$} \\
\cline { 2 - 5 } & Volume, $\mathrm{m}^{3}$ & Activity, $\mathrm{TBq}$ & Volume, $\mathrm{m}^{3}$ & Activity, TBq \\
\hline Dnepropetrovsky Combine & 702.0 & 6,030 & 60.0 & 0.0162 \\
Kievsky Combine & $2,025.9$ & 5,430 & 413.0 & 1.76 \\
Lvovsky Combine & 683.4 & 7.70 & - & - \\
Odessky Combine & 511.3 & 40.0 & 137.5 & 0.110 \\
Kharkovsky Combine & $1,698.9$ & 9.54 & 2.0 & $9.46 \times 10^{-6}$ \\
\hline Total & $\mathbf{5 , 6 2 1 . 5}$ & $\mathbf{1 1 , 9 0 0}$ & $\mathbf{6 1 2 . 5}$ & $\mathbf{1 . 8 9}$ \\
\hline
\end{tabular}


Table 3. Estimated total radioactive waste inventory in the ChEZ Facilities (summarized data from reports generated by the ChNPP Site and Kompleks State Specialized Enterprise (MESU 2010).

\begin{tabular}{lcrr}
\hline Type of facility/location & $\begin{array}{c}\text { Number of } \\
\text { facilities }\end{array}$ & $\begin{array}{c}\text { Radioactive waste } \\
\text { volume, } \mathbf{~ m}^{\mathbf{3}}\end{array}$ & Activity, TBq \\
\hline $\begin{array}{l}\text { Radioactive waste disposal sites } \\
\text { (RWDS) }\end{array}$ & 3 & $631,518.9$ & $5,420.0$ \\
$\begin{array}{l}\text { Radioactive waste interim } \\
\text { localization sites (RWILS) }\end{array}$ & 9 & $1,296,588.0$ & $1,840.0$ \\
$\begin{array}{l}\text { Shelter Facility (including the } \\
\text { ChNPP industrial site) }\end{array}$ & 1 & $662,500.0$ & $740,000.0$ \\
ChNPP waste storage facilities & 4 & $19,794.0$ & 385.0 \\
ChEZ soils & - & $11,000,000.0$ & $8,130.0$ \\
\hline Total & & $\mathbf{1 3 , 6 1 0 , 4 0 9 . 0}$ & $\mathbf{7 5 5 , 7 7 5 . 0}$ \\
\hline
\end{tabular}


Table 4. Radioactive Waste in the ChNPP Storage Facilities as of January 1, 2010 (MESU 2010).

\begin{tabular}{lrr}
\hline Facility name and group of waste & Volume, $\mathbf{~ m}^{\mathbf{3}}$ & Activity, TBq \\
\hline $\begin{array}{l}\text { Solid radioactive waste } \\
\quad \text { Solid radioactive waste storage facility, }\end{array}$ & $2,502.43$ & 132 \\
$\quad \begin{array}{l}\text { Unit 1 (low and medium level waste) } \\
\text { Interim solid high level waste storage } \\
\text { facility }\end{array}$ & 1.23 & 1.91 \\
\hline $\begin{array}{l}\text { Liquid radioactive waste storage facility } \\
\quad \text { Liquid radioactive waste storage facility, }\end{array}$ & $13,812.88$ & 275 \\
$\quad \begin{array}{l}\text { Unit 1 (low and medium level waste) } \\
\text { Liquid and solid radioactive waste } \\
\text { storage facility, Unit 2 (low and medium } \\
\text { level waste) }\end{array}$ & $5,800.94$ & 110 \\
\hline
\end{tabular}


Table 5. Estimated Activity in the Chernobyl Exclusion Zone (IAEA 2006).

ChEZ element

ChEZ territory

ChNPP Cooling Pond

Radioactive Waste Disposal Sites (RWDS)

Radioactive Waste Interim Localization Sites

(RWILS)

Shelter Facility (including fuel assemblies in the

ChNPP Reactor Unit \# 4 Reactor Hall and retention

pool)

ChNPP spent nuclear fuel (Reactor Units \# 1, 2, and

3 and Spent Nuclear Fuel Storage Facility-1
Activity, PBq

Total ${ }^{137} \mathrm{Cs}$

8.13

0.22

5.49

1.84

740

480

${ }^{90} \mathrm{Sr}$

Transuranic

5.5

0.19

2.5

Waste

0.13

0.13
0.02

3.6

0.3

0.09

1.1

1.8

0.04

0.7

10 